\title{
Ryszard Żabiński
}

Wyższa Szkoła Zarządzania „Edukacja” we Wrocławiu

e-mail: rzabinski@vp.pl

\section{MODEL BIZNESOWY \\ A WZROST WARTOŚCI PRZEDSIĘBIORSTWA}

\section{BUSINESS MODEL VERSUS AN INCREASE IN THE VALUE OF ENTERPRISE}

DOI: $10.15611 / \mathrm{pn} .2018 .526 .11$

JEL Classification: L21

Streszczenie: W pracy analizowano modele biznesowe największych polskich przedsiębiorstw oraz wybranych firm o największej dynamice wzrostu wartości. Celem pracy było wskazanie, jak stosowane modele biznesowe wpływały na wzrost wartości firm. Badane przedsiębiorstwa osiągnęły dużą wartość majątku i wysoką dynamikę jego wzrostu, głównie dzięki unikatowej propozycji wartości. Większość uzyskanych efektów w zakresie oferowanej odbiorcy wartości wiązała się ze stosowaniem innowacji. W pierwszej grupie podmiotów dominujące znaczenie dla szybkiego i trwałego wzrostu wartości przedsiębiorstwa miały: wzrost organiczny osiągnięty dzięki umiejętnemu pozyskiwaniu kapitału, przejęcia innych firm, tworzenie własnych firm, szybka internacjonalizacja. W drugiej grupie do najważniejszych komponentów modelu biznesowego zaliczono umiejętność pozyskiwania finansowania, wykorzystywania trendów społecznych, innowacje produktowe, unikatowe kompetencje umożliwiające wchodzenie na rynki zagraniczne.

Słowa kluczowe: zarządzanie wzrostem wartości, wartość dla klienta, model biznesowy, internacjonalizacja.

Summary: The business models of the largest Polish enterprises as well as selected companies with the highest growth rate of value were analyzed. The aim of the work was to show how, in the group of companies surveyed, the applied business models influenced the growth of the value of companies. The surveyed enterprises achieved high asset value and high growth dynamics, mainly due to the unique value proposition. In the first group of entities in the applied business models, the dominant importance for a fast, sustained growth in the value of the enterprise was: organic growth achieved thanks to skilful acquisition of capital, takeovers of other companies, creation of own companies, fast internationalization. In the second group, the most important components of the business model include the ability to obtain financing, including from the capital market, the ability to use social trends, product innovations, and unique competences enabling quick entry into foreign markets.

Keywords: business models of the company, increase in the value of the company, marketing, innovations. 


\section{Wstęp}

W pracy przedstawiono zagadnienia związane z zarządzaniem wzrostem wartości przedsiębiorstwa. Analizowano modele biznesowe największych polskich przedsiębiorstw w roku 2015, jak również wybranych firm o największej dynamice wzrostu wartości. Celem pracy było przedstawienie związku pomiędzy kompozycją modelu biznesowego a uzyskiwanymi efektami w postaci wzrostu wartości przedsiębiorstwa.

\section{Hipoteza badawcza}

W pracy założono, że zarządzanie wzrostem wartości przedsiębiorstwa stanowi podstawowy problem właścicieli i menedżerów firm. Najszybszy wzrost umożliwiają: przejęcia, internacjonalizacja, tworzenie własnych firm. Sposób ekspansji i wzrostu wartości firmy stanowi jeden z najważniejszych komponentów modelu biznesowego. Przejęcia, internacjonalizacja, tworzenie własnych firm obarczone są najwyższym ryzykiem i wymagają posiadania przez przedsiębiorstwo unikatowych zasobów i kompetencji. Takimi umiejętnościami dysponują z reguły firmy, które osiągnęły już wysoki wzrost organiczny, gwarantujący dominującą pozycję rynkową. W takich firmach innowacyjne modele biznesowe są oparte nie tylko na propozycji wartości dla odbiorcy, innowacjach, ale przede wszystkim na umiejętnościach i zasobach z zakresu przejęć, internacjonalizacji i tworzenia własnych firm, co umożliwia w największym stopniu osiągnięcie celu, jakim jest wysoki, stabilny i trwały wzrost wartości.

$\mathrm{Na}$ etapie wzrostu organicznego i osiągania przez przedsiębiorstwo znaczącej pozycji rynkowej do najważniejszych komponentów modelu biznesowego należy zaliczyć: umiejętność pozyskiwania finansowania kapitału, w tym z rynku kapitałowego, umiejętność wykorzystywania trendów społecznych, innowacje produktowe, unikatowe kompetencje umożliwiające szybką internacjonalizację (tzw. urodzeni globaliści).

\section{Metody badawcze}

W pracy zastosowano metodę case researches, polegającą na pogłębionym badaniu przypadków. Analizowano modele biznesowe, sposób ekspansji wybranych przedsiębiorstw z kapitałem polskim, które osiągnęły od początku transformacji gospodarczej w Polsce najwyższy wzrost wartości majątku [Lista 100 2016, s. 10] oraz przedsiębiorstw o ponadprzeciętnym średnim wzroście majątku w 2015 roku. Wykorzystano również dane źródłowe analizowanych przedsiębiorstw.

Zastosowano rodzaj badania eksploracyjnego, który miał na celu rozpoznanie problemu oraz postawienie hipotez i wstępnych wyjaśnień. W pracy wykorzystano też analizę opisową, która pozwoliła na identyfikację, ze źródeł wtórnych i pierwot- 
nych, działań w ramach przypadków najlepszych praktyk przedsiębiorstw w zakresie budowy modelu biznesowego, sposobu ekspansji.

Na podstawie studiów literaturowych i wstępnej analizy materiałów z badanych sektorów założono, że w warunkach zaostrzającej się walki konkurencyjnej na światowych rynkach badane firmy, aby zdobyć/utrzymać satysfakcjonującą pozycję rynkową i odróżnić się od rywali, dążyły do aktywnego kształtowania optymalnej kompozycji wartości dostosowanej do potrzeb i oczekiwań obsługiwanych rynków. Jednocześnie firmy aktywnie współdziałały z innymi podmiotami w procesie kształtowania i komunikowania wartości.

\section{Model biznesowy a wzrost wartości przedsiębiorstwa}

Niedostateczny rozwój badań nad dynamiką i procesami rozwoju modelu biznesowego przedsiębiorstwa powoduje, że menedżerowie stają przed wyzwaniem - jak należy zmieniać model biznesowy, aby pobudzać dalszy wzrost przedsiębiorstwa?

Zdaniem M.W. Johnsona, C.M. Christensena i H. Kagermanna źródłem powodzenia jest zignorowanie kwestii modeli biznesowych i skoncentrowanie się na możliwościach zaspokojenia potrzeb rzeczywistego konsumenta. Należy szczegółowo określić, w jaki sposób firma odpowie na tę potrzebę, osiągając przy tym zysk. Trzeba porównać nowy model biznesowy z istniejącym i sprawdzić, jak wiele trzeba zmienić, by skorzystać z nadarzającej się okazji. Każdy model biznesowy zawiera cztery podstawowe elementy: propozycję wartości dla klienta, formułę zysków, kluczowe zasoby i kluczowe procesy.

Propozycja wartości dla klienta (Customer Value Proposition - CVP) to pomoc dla klientów w wykonaniu pewnego zadania. Przez „zadanie” należy rozumieć fundamentalny problem, który w określonej sytuacji wymaga rozwiązania. Oferta rozwiązująca problem lub zaspokajająca potrzebę obejmuje nie tylko sprzedawany produkt lub usługę, ale także sposób sprzedaży [Johnson, Christensen, Kagermann 2012, s. 120-121].

$\mathrm{W}$ pracy przedstawiono m.in. wybrane przedsiębiorstwa znajdujące się $\mathrm{w}$ grupie największych stu polskich firm prywatnych. Analizowane przedsiębiorstwa osiągnęły dużą wartość majątku dzięki unikatowej propozycji wartości, polegającej m.in. na:

- udostępnieniu nowej kategorii produktów/usług, przeznaczonej dla bardziej zamożnych segmentów rynku, również dużym grupom mniej zamożnych konsumentów,

- zaproponowaniu nowego, odmiennego podejścia do sposobu obsługi klienta, wprowadzeniu procedur ułatwiających konsumentowi korzystanie z danej usługi, co przy stosowaniu wcześniejszych rozwiązań nie było możliwe,

- oferowaniu produktów konwergentnych/systemowych,

- umożliwieniu konsumentom współtworzenia oferowanych produktów/usług,

- oferowaniu produktów/usług po znacznie niższych cenach, przy zachowaniu lub nawet zwiększeniu ich jakości, 
- stworzeniu silnej marki w połączeniu ze znacznymi innowacyjnymi modyfikacjami produktu,

- oferowaniu produktów o bardzo wysokiej jakości, odznaczających się najlepszymi parametrami w branży,

- głębokiej modyfikacji zestawu korzyści, który uzyskuje nabywca produktu,

- umożliwieniu konsumentowi korzystnego dostępu do dużej sieci usługowej w skali rynków: krajowego i zagranicznych,

- tworzeniu wartości dla odbiorcy w nowych przestrzeniach rynkowych.

Większość uzyskanych efektów w zakresie oferowanej odbiorcy wartości wiązała się ze stosowaniem innowacji: produktu, procesu, marketingu czy modelu biznesowego. Konsumentowi proponowano nowy sposób rozwiązania jego problemów zakupowych czy finansowych. Oferowano mu produkty o nowych właściwościach. Podejmowano działania poszerzające rynek, umożliwiające sprzedawanie produktów uznawanych dotąd za dostępne jedynie dla rynków górnych i średnich również mniej zamożnym konsumentom.

W definicji innowacji sensu largo podkreśla się, że stanowi ona wszelkie pozytywnie wdrożone zmiany, postrzegane jako nowe z punktu widzenia wprowadzającej je jednostki. Innowacje mogą przybierać postać zarówno materialną (innowacje produktowe), jak i niematerialną (innowacje organizacyjne) [Kalinowski 2010, s. 18 i 26$]$.

Geoffrey A. Moore wyróżnia następujące rodzaje innowacji: przełomową, zastosowania, produktu, procesu, eksperymentalną, marketingu, modelu biznesowego. Menedżerowie często zastanawiają się, na jaki rodzaj innowacji postawić. Otóż w różnych fazach rozwoju rynku można zauważyć dominację określonych rodzajów innowacji. Innowacje: przełomowe, zastosowania, produktu występują najczęściej we wczesnych fazach rozwoju rynku; procesu, eksperymentalna, marketingu w okresie wzrostu i stabilizacji; natomiast: modelu biznesowego i strukturalna w fazie schyłkowej. Efektywne zarządzanie innowacjami polega na zastosowaniu odpowiedniego rodzaju innowacji w zależności od występującej fazy rozwoju rynku [Moore 2005, s. 58-62].

C.K. Prahalad i M.S. Krishnan zwracają uwagę na pojawianie się nowych modeli biznesu, rozdrabnianie się tradycyjnych struktur organizacyjnych, centralną pozycję technologii informatycznej w procesach biznesowych, współpracę drobnych, wyspecjalizowanych firm ze znacznie większymi, globalnymi. Tradycyjny pogląd na wartość, skoncentrowany na firmie i jej produkcie, ustępuje miejsca skupianiu się na wartości jako spersonalizowanym doświadczeniu i na współtworzeniu wartości. Autorzy określają dwa filary następnej generacji innowacji jako: $\mathrm{N}=1$ oraz $\mathrm{R}=\mathrm{G}$. Wartość określana przez doświadczenie, w danym czasie, przy współudziale pojedynczego konsumenta, określono jako $\mathrm{N}=1$. $\mathrm{Z}$ kolei trend korzystania z zasobów z wielu źródeł (lokalnych lub globalnych), a nie tylko z zasobów danej firmy i jej filii, oznaczono jako R = G [Prahalad, Krishnan 2010, s. 9-11]. 
W grupie analizowanych przedsiębiorstw [Lista 100 2016, s. 10 i Bisnode Polska 2017, s. 8] próby wykorzystania innowacyjnych modeli biznesu, opartych na formule $\mathrm{R}=\mathrm{G}$ i $\mathrm{N}=1$, występowały w dużej mierze wśród firm działających stosunkowo krótko. Wykorzystywały one w szerokim zakresie najnowsze technologie informatyczne w zarządzaniu i do oferowania wartości, dokonywały szybkiej internacjonalizacji, często z pominięciem rozwoju organicznego na rodzimym rynku.

Implementacja modelu biznesowego sprowadza się m.in. do synergii różnych działań z obszarów: rachunkowości zarządczej, finansów, marketingu czy informatyki. Synergia tych działań przynosi wymierne wyniki rozwoju przedsiębiorstwa i wzrostu jego wartości. Istotna jest tu rola strategii marketingowej. W przedsiębiorstwie nowego wieku polega ona na zarządzaniu wiedzą zawartą w aktywach dla maksymalizacji wartości przedsiębiorstwa. Wynika stąd, że inwestycje marketingowe powinny być zorientowane na tworzenie wartości dla udziałowców i właścicieli oraz stanowić o lepszym zaspokojeniu potrzeb klienta [Golik-Górecka 2008, s. 42 i 52-53].

Innowacje w zakresie modelu biznesowego mają o wiele większe znaczenie dla sukcesu przedsiębiorstwa niż tworzenie lub też doskonalenie istniejących produktów i usług. Należy jednak pamiętać, że firmy o ugruntowanej pozycji na rynku nie powinny zbyt lekkomyślnie podejmować innowacji w modelu biznesowym. Często bowiem można stworzyć nowe produkty bez konieczności wprowadzania tak fundamentalnych zmian [Johnson, Christensen, Kagermann 2012, s.129].

\section{Wartość dla klienta - najważniejszy element modelu biznesowego}

W tabeli 1 przedstawiono ofertę wartości analizowanych przedsiębiorstw, zawartą w ich modelach biznesowych.

Analizowano wszystkie spółki z listy „100”, w których większościowy udział należał do polskiego przedsiębiorcy lub grupy takich osób działających wspólnie. O miejscu w rankingu decydowała wartość firmy (Enterprise Value - EV). W przypadku spółek nienotowanych na Giełdzie Papierów Wartościowych EV obliczono jako iloczyn zysku operacyjnego oraz mnożnika wycenowego na poziomie typowym dla danej branży. Wykorzystano dane finansowe za pełny rok obrotowy (za 2015 rok lub wcześniejsze) [Lista 100 2016, s. 32].

W drugiej części tabeli 1 przedstawiono firmy, w tym z udziałem kapitału zagranicznego, które w 2015 roku najszybciej zwiększały swoją wartość. Wartość przedsiębiorstwa $(W)$ jest średnią ważoną wartości ich majątku $(W m)$ i wartości dochodowej $(W d)$, według wzoru $s^{\prime} W=(W m+2 W d) / 3$. Majątek wyceniono na podstawie średniej arytmetycznej jego wartości likwidacyjnej oraz wartości księgowej netto spółki, która kwotowo odpowiada kapitałowi własnemu firmy pomniejszonemu o wartości niematerialne i prawne. Wartość dochodowa jest średnią z zysków z lat 2013-2015. Wycena wartości nie uwzględnia marek i dotyczy końca 2015 roku [Raport 2017, s. 8]. 
Tworzenie innowacji modelu biznesowego w połączeniu z innowacjami produktowymi prowadzącymi do stworzenia oferty produktów systemowych może być ofertą wartości przyczyniającą się do szybkiego wzrostu wartości przedsiębiorstwa.

Dla przykładu, Telewizja Polsat (obecnie Cyfrowy Polsat) to tania płatna telewizja dostępna po raz pierwszy poza wielkimi miastami. Polsat utrzymał tę wartość również w modelu płatnej telewizji cyfrowej. Dzięki temu zapewnił sobie wzrost organiczny na rodzimym rynku i pozycję najbardziej dochodowej grupy medialnej w Polsce. Osiągane przychody umożliwiły firmie akwizycję w innych sektorach: telekomunikacyjnym, energetycznym, finansowym, ubezpieczeniowym, RTV i AGD. Synergia działań w tak wielu obszarach umożliwiła firmie oferowanie produktów konwergentnych/systemowych.

Produkty systemowe dostarczają nabywającym je klientom korzyści jedynie pod warunkiem sprawnego funkcjonowania całego systemu, obejmującego wiele różnych produktów i usług oraz korzystających z nich użytkowników. Podstawowym problemem, który towarzyszy rozwojowi produktów systemowych, jest potrzeba określania i upowszechniania standardów, które mogłyby być wspólnie wykorzystywane przez wielu producentów i użytkowników. Opracowanie i wprowadzenie standardu produktu lub usługi pochłania znaczne koszty, jest ryzykowne i wymaga istnienia lub stworzenia trwałych relacji z użytkownikami standardu [Szymura-Tyc 2012, s. 54].

Cyfrowy Polsat wykazał się we wspomnianym obszarze innowacyjnością, która stanowiła jeden z głównych czynników rozwoju. Firma wykorzystała, po raz pierwszy na świecie, częstotliwości $1800 \mathrm{MHz}$ do Internetu LTE. Obecnie jest to już standard.

Wartością stworzoną dla klienta może być również rozbudowane portfolio marek oraz współtworzenie wartości przez konsumentów. Takie rozwiązanie zastosował LPP, twórca popularnych marek odzieżowych fast fashion.

Wartością oferowaną $\mathrm{w}$ modelu biznesowym jest też ogromna różnorodność oferty połączona z niskokosztowym modelem działania. Dzięki takiemu rozwiązaniu firma CCC osiągnęła ogromny wzrost wartości majątku oraz dokonała udanej internacjonalizacji, tworząc drugą pod względem wielkości w Europie sieć salonów obuwniczych.

Oferowaną wartością są również innowacje: produktowe, modelu biznesowego czy marketingu. Przykładem może być Polpharma, której największą oferowaną wartością były innowacje produktowe - leki biopodobne. Innowację modelu biznesowego wykorzystywała Grupa Kapitałowa Kruk. Ta największa w Polsce firma windykacyjna jako pierwsza zmieniła podejście do klientów - dłużników. Zrezygnowała z modelu bezwzględnej egzekucji wierzytelności na rzecz modelu spłaty długu na raty, empatii wobec dłużnika, pomocy w rozwiązywaniu jego problemu.

Ofertą wartości firm działających w branży finansowej jest często ponadprzeciętny wzrost zainwestowanego kapitału przy adekwatnym poziomie ryzyka. Oferta 
Tabela 1. Wybrane firmy o najwyższej wartości i najwyższej dynamice wzrostu wartości a ich propozycja dla odbiorcy i dominujący charakter ekspansji

\begin{tabular}{|c|c|c|c|}
\hline Firma & Propozycja wartości & $\begin{array}{c}\text { Dominujący } \\
\text { charakter ekspansji }\end{array}$ & Osiągnięte efekty \\
\hline $\begin{array}{l}\text { Cyfrowy } \\
\text { Polsat }\end{array}$ & $\begin{array}{l}\text { Tania płatna telewizja, dostępna } \\
\text { po raz pierwszy poza wielkimi } \\
\text { miastami, oferta produktów } \\
\text { systemowych }\end{array}$ & $\begin{array}{l}\text { Wzrost organiczny na różnych rynkach } \\
\text { krajowych, przejęcia (kluczowe przejęcie - } \\
\text { Polkomtel, wartość } 18 \text { mld zł) }\end{array}$ & $\begin{array}{l}\text { Największa polska firma prywatna. Wartość } \\
\text { fírmy w } 2016 \text { r. - 26,7 mld zł. Sprzedaż } \\
\text { w } 2015 \text { r. - } 2,099 \text { mld zł, zysk netto } 446,1 \mathrm{mln} \text { zł, } \\
\text { średnia ważona wzrostu - 20,72\% }\end{array}$ \\
\hline LPP & $\begin{array}{l}\text { Portfolio popularnych marek fast } \\
\text { fashion, próby współtworzenia } \\
\text { wartości przez konsumentów }\end{array}$ & $\begin{array}{l}\text { Wzrost organiczny (ekspansja centrów } \\
\text { handlowych, wykorzystanie private equity, } \\
\text { kapitału z GPW), internacjonalizacja }\end{array}$ & $\begin{array}{l}\text { 2. miejsce na liście „100”, wartość firmy - } \\
8,8 \text { mld zł, sprzedaż w } 2015 \text { r. }-5,1 \text { mld zł, } \\
\text { EBIT- } 503 \text { mln zł }\end{array}$ \\
\hline $\mathrm{CCC}$ & $\begin{array}{l}\text { Różnorodność oferty, } \\
\text { niskokosztowy model działania, } \\
\text { portfolio } 67 \text { marek towarowych }\end{array}$ & $\begin{array}{l}\text { Wzrost organiczny (ekspansja centrów } \\
\text { handlowych, wykorzystanie kapitału z GPW), } \\
\text { internacjonalizacja }\end{array}$ & $\begin{array}{l}\text { 3. miejsce na liście „100”, druga sieć salonów } \\
\text { obuwniczych w Europie. Wartość firmy - } \\
7,5 \text { mld zł, sprzedaż w } 2015 \text { r. }-2,3 \text { mld zł, } \\
\text { EBIT - } 257 \text { mln zł }\end{array}$ \\
\hline Polpharma & $\begin{array}{l}\text { Innowacyjna oferta produktowa, } \\
\text { leki biopodobne }\end{array}$ & $\begin{array}{l}\text { Wzrost organiczny (leki generyczne), } \\
\text { przejęcia, internacjonalizacja }\end{array}$ & $\begin{array}{l}\text { 5. miejsce na liście „100”, wartość firmy } \\
5 \mathrm{mld} \text { zł, sprzedaż } 3 \mathrm{mld} \text { zł, EBIT - } 380 \mathrm{mln} \text { zł }\end{array}$ \\
\hline $\begin{array}{l}\text { Grupa } \\
\text { Kapitałowa } \\
\text { Kruk }\end{array}$ & $\begin{array}{l}\text { Rezygnacja z modelu } \\
\text { bezwzględnej egzekucji } \\
\text { wierzytelności na rzecz modelu } \\
\text { spłaty długu na raty, empatii } \\
\text { wobec dłużnika }\end{array}$ & $\begin{array}{l}\text { Wzrost organiczny, wykorzystanie private } \\
\text { equity, wykorzystanie kapitału z GPW } \\
\text { przejęcia, internacjonalizacja }\end{array}$ & $\begin{array}{l}\text { 6. miejsce na liście „100” } \\
\text { Wartość firmy - } 4,9 \text { mld zł, sprzedaż - } \\
611 \text { mln zł, EBIT } 251 \mathrm{mln} \text { zł. Lider rynku } \\
\text { wierzytelności w Polsce }\end{array}$ \\
\hline $\begin{array}{l}\text { Getin } \\
\text { Holding }\end{array}$ & $\begin{array}{l}\text { Tworzenie wartości poprzez } \\
\text { osiąganie wysokiej stopy zwrotu } \\
\text { z inwestycji, wymiernych korzyści } \\
\text { dla akcjonariuszy }\end{array}$ & $\begin{array}{l}\text { Wykorzystanie kapitału z GPW, przejęcia, } \\
\text { tworzenie własnych firm, internacjonalizacja. } \\
\text { Holding działa w modelu ,funkcjonalnym”, } \\
\text { stanowiąc dla wszystkich podmiotów w grupie } \\
\text { centrum kompetencji w kluczowych obszarach } \\
\text { biznesowych. }\end{array}$ & $\begin{array}{l}\text { Miejsca na liście „100”: Idea Bank - 27., } \\
\text { LC Corp. - 32., Getin Noble Bank - 43., } \\
\text { Wartość firmy Idea Bank - 1,7 mld zł, sprzedaż } \\
792 \text { mln zł, EBIT - } 105 \text { mln zł }\end{array}$ \\
\hline Livechat & $\begin{array}{l}\text { Strategia superwartości, oferowanie } \\
\text { najwyższej jakości usług przy } \\
\text { najniższym poziomie cen }\end{array}$ & $\begin{array}{l}\text { Wykorzystanie kapitału z GPW. } \\
\text { Internacjonalizacja, ,urodzony globalista”, } \\
\text { niskokosztowy model działania }\end{array}$ & $\begin{array}{l}\text { 40. miejsce na liście „100”. Wartość firmy - } \\
1,2 \mathrm{mld} \text { zł, sprzedaż - } 53 \mathrm{mln} \text { zł, EBIT - } \\
35 \mathrm{mln} \text { zł }\end{array}$ \\
\hline
\end{tabular}




\begin{tabular}{|c|c|c|c|}
\hline Mlekovita & $\begin{array}{l}\text { Pierwsza na polskim rynku } \\
\text { marka dla mleka, mleko UHT } \\
\text { w kartonach, rozbudowane, } \\
\text { innowacyjne portfolio } \\
\text { produktowe }\end{array}$ & $\begin{array}{l}\text { Wzrost organiczny, przejęcia, } \\
\text { internacjonalizacja (największy polski } \\
\text { eksporter produktów mleczarskich) }\end{array}$ & $\begin{array}{l}\text { 86. pod względem wielkości prywatna firma w } \\
\text { Polsce. Wartość firmy - } 751 \text { mln zł. Przychody - } \\
3,4 \text { mld zł, EBIT - } 50 \text { mln zł. Największa polska } \\
\text { grupa mleczarska }\end{array}$ \\
\hline \multicolumn{4}{|c|}{ Firmy o największej dynamice wzrostu wartości } \\
\hline $\begin{array}{l}11 \text { bit } \\
\text { studios SA }\end{array}$ & $\begin{array}{l}\text { Głęboka modyfikacja gry } \\
\text { komputerowej, polegająca na } \\
\text { zmianie perspektywy użytkownika }\end{array}$ & $\begin{array}{l}\text { Wykorzystanie kapitału z GPW, } \\
\text { internacjonalizacja dzięki innowacjom } \\
\text { produktowym, „urodzony globalista” }\end{array}$ & $\begin{array}{l}\text { Globalny sukces produktu w } 2014 \text { r. } \\
\text { Pięciokrotny wzrost wartości spółki na giełdzie } \\
\text { w } 2014 \text { r. Sprzedaż } 2015 \text { r. - } 22,7 \text { mln zł, zysk } \\
\text { netto - } 12,7 \text { mln zł, średnia ważona stopa } \\
\text { wzrostu - } 128,09 \%\end{array}$ \\
\hline $\begin{array}{l}\text { Carefleet } \\
\text { SA }\end{array}$ & $\begin{array}{l}\text { Długoterminowy leasing } \\
\text { (dla przedsiębiorstw } \\
\text { i leasing konsumencki) }\end{array}$ & $\begin{array}{l}\text { Wzrost organiczny dzięki coraz większej } \\
\text { popularności długoterminowego leasingu }\end{array}$ & $\begin{array}{l}\text { Sprzedaż } 2015 \text { r. - 186,7 mln zł, zysk netto - } \\
17,6 \text { mln zł, średnia ważona wzrostu - 118,1\% }\end{array}$ \\
\hline $\begin{array}{l}\text { Biofood } \\
\text { Ciechocin }\end{array}$ & $\begin{array}{l}\text { Produkcja innowacyjnych, } \\
\text { ekologicznych soków } \\
\text { z kwaszonych warzyw }\end{array}$ & $\begin{array}{l}\text { Wzrost organiczny dzięki innowacjom } \\
\text { produktowym }\end{array}$ & $\begin{array}{l}\text { Sprzedaż w } 2015 \text { r. }-5,3 \text { mln zł, zysk netto - } \\
1,2 \text { mln zł, średnia ważona stopa wzrostu } \\
111,53 \%\end{array}$ \\
\hline Zdrofit & $\begin{array}{l}\text { Upowszechnienie kart MultiSport } \\
\text { oferujących nielimitowany dostęp } \\
\text { do większości siłowni w Polsce }\end{array}$ & $\begin{array}{l}\text { Wzrost organiczny dzięki innowacjom } \\
\text { w systemie dystrybucji usług }\end{array}$ & $\begin{array}{l}\text { Sprzedaż w } 2015 \text { r. - } 17,5 \text { mln zł, zysk netto } \\
-2,7 \text { mln zł. Średnia ważona stopa wzrostu - } \\
93,39 \%\end{array}$ \\
\hline $\begin{array}{l}\text { Zdrojowa } \\
\text { Invest }\end{array}$ & $\begin{array}{l}\text { Budowa hoteli w Kołobrzegu, } \\
\text { w pierwszej linii brzegowej } \\
\text { - odkrycie nowej przestrzeni } \\
\text { rynkowej }\end{array}$ & $\begin{array}{l}\text { Wzrost organiczny dzięki innowacyjnemu } \\
\text { modelowi biznesowemu }\end{array}$ & $\begin{array}{l}\text { Sprzedaż w } 2015 \text { r. }-16,6 \mathrm{mln} \text { zł, zysk netto - } \\
53,8 \text { tys. zł, średnia ważona wzrostu - 72,37\% }\end{array}$ \\
\hline Selena & $\begin{array}{l}\text { Prekursor branży profesjonalnej } \\
\text { chemii budowlanej w Polsce }\end{array}$ & $\begin{array}{l}\text { Wykorzystanie kapitału z GPW, wzrost } \\
\text { organiczny dzięki innowacjom produktowym, } \\
\text { internacjonalizacja }\end{array}$ & $\begin{array}{l}\text { Sprzedaż w } 2015 \text { r. - 276,4 mln zł, zysk netto - } \\
18,4 \text { mln zł, średnia ważona wzrostu - 33,67\% }\end{array}$ \\
\hline
\end{tabular}

Źródło: opracowanie własne na podstawie [Lista 100 2016]. 
taka może być możliwa dzięki innowacyjnym modelom biznesowym, pozwalającym uzyskiwać znaczące efekty synergiczne w grupie wzajemnie powiązanych i współpracujących ze sobą spółek. Przykładem takiego podejścia jest Getin Holding, który działał w modelu „funkcjonalnym”, stanowiąc dla wszystkich podmiotów w Grupie centrum kompetencji w kluczowych obszarach biznesowych.

Oferowanie produktów/usług po znacznie niższych cenach, przy zachowaniu lub nawet zwiększeniu ich jakości, jest stosowaniem strategii superwartości, zakładającej oferowanie najwyższej jakości przy najniższym poziomie cen. Realizacja takiej strategii wymaga najczęściej dostępu do unikatowych technologii lub też unikatowego wykorzystania powszechnie dostępnych wysokich technologii.

Przykładem może być propozycja wartości firmy informatycznej Livechat działającej na rynku biznesowego czatu. Produkt Livechatu jest uznawany za największy sukces polskich przedsiębiorców na rynku globalnych technologii. Livechat stworzył oprogramowanie dla firm umożliwiające prowadzenie rozmów z klientami w sieci. Za korzystanie z Live Chata trzeba było płacić tylko 33 dolary miesięcznie, a cała sprzedaż odbywała się przez Internet, aż $99 \%$ klientów spółki pochodziło z zagranicy. Marża operacyjna firmy osiągała nawet poziom $66 \%$.

Oferowanie wartości dla klientów polega również na stworzeniu silnej marki lub portfolio marek. Menedżerowie dobrze zarządzanej marki najlepiej rozumieją potrzeby klientów. Osiągnięcie tego celu wymaga dużych umiejętności w zakresie zarządzania doświadczeniami klientów (consumer experience). Doświadczenia, które klient ma z daną firmą, jej produktami, sposobem sprzedaży, promocji, wyrażają się w wielu wskaźnikach dotyczących świadomości marki, postrzegania jej jakości, wartości czy prestiżu, a wreszcie w skłonności do rekomendacji. Pozytywne doświadczenia klienta związane z firmą można uzyskać poprzez: personalizację oferty, ograniczanie czasu i wysiłku klienta związanego z zakupem i użytkowaniem produktu, badanie i spełnianie oczekiwań klienta, budowanie wiarygodności, rozwiązywanie problemów konsumenta, empatię. Duże znaczenie może mieć stworzenie marki w kategorii produktowej, w której marka ma mniejsze znaczenie.

Przykładem jest Mlekovita, która jako pierwsza na polskim rynku stworzyła markę dla mleka, wprowadzając jednocześnie innowację produktową, polegającą na oferowaniu mleka UHT w kartonach.

Wartość dla klienta można również budować poprzez zastosowanie innowacji produktowych przy wykorzystaniu różnego rodzaju technik kreatywnych, np. analizy morfologicznej - metody analityczno-kombinatorycznej, których celem jest rozwiązywanie problemów poprzez analizę ich części składowych [Trias de Bes, Kotler 2013, s. 81].

Udanym przykładem zastosowania tej metody może być polska firma 11 bit studios SA, producent gry komputerowej „This War of Mine” (część druga tab. 1). Okazała się ona przebojem na rynkach międzynarodowych, zapewniając firmie znaczną poprawę sytuacji finansowej i rynkowej. Głęboka modyfikacja produktu, jakim była gra komputerowa, polegała na zmianie perspektywy użytkownika. 
W klasycznych produktach tego typu użytkownik wcielał się w postać żołnierza, dowódcy etc. W grze „This War of Mine” „stawał się” zwykłym cywilem, którego zadaniem było przeżycie konfliktu zbrojnego, rozwiązywanie dylematów etycznych itd.

Często ofertą wartości są innowacyjne produkty, będące odpowiedzią na zapotrzebowanie konsumentów związane z silnymi trendami społecznymi.

Przykładem jest firma Biofood Ciechocin, która uruchomiła produkcję ekologicznych soków z kwaszonych warzyw. Nowa technologia kwaszenia warzyw zwiększyła znacznie przyswajalność składników mineralnych zawartych w sokach. W tym przypadku technologię kwaszenia zastosowano po raz pierwszy w odniesieniu do niektórych warzyw, np. buraka.

Propozycja wartości dla odbiorcy nie polega jedynie na oferowaniu nieznanych dotąd produktów czy usług. Znaczące efekty można uzyskać, oferując nowy, lepszy sposób rozwiązania problemu odbiorcy.

Firma Zdrofit dokonała przełomu na rynku usług fitness, upowszechniając karty MultiSport, dzięki którym klienci uzyskali nielimitowany dostęp do większości siłowni w Polsce. Wystawca kart, Benefit Systems, rozwinął współpracą z sieciami siłowni i przejął mniejszościowy pakiet Zdrofitu. Dzięki takim rozwiązaniom możliwy był szybki rozwój sieciowy firmy Zdrofit.

Inny problem klientów rozwiązała firma Carefleet SA, oferując długoterminowy leasing konsumencki. Powstało rozwiązanie dla indywidualnych konsumentów, których nie stać było na kupno za gotówkę nowego samochodu.

Wartość dla odbiorcy można również tworzyć, odkrywając nowe przestrzenie rynkowe. Według W. Chan Kima i Renée Mauborgne, tworzenie nowych przestrzeni rynkowych jest systematycznym odkrywaniem nowych możliwości na podstawie istniejących danych. Innowacyjne myślenie, prowadzące do tworzenia nowych rynków i reaktywowania rynków istniejących, sprowadza się do badania: branż substytucyjnych, grup strategicznych, grup kupujących, dóbr komplementarnych, funkcjonalno-emocjonalnej orientacji branży, skutków ważnych trendów [Chan Kim, Mauborgne 2003, s. 8-9].

Firma Zdrojowa Invest odkryła nową przestrzeń rynkową, inwestując w budowę hoteli w Kołobrzegu w pierwszej linii brzegowej. Wcześniej inwestorzy rezygnowali z takich przedsięwzięć w obawie o wykorzystanie hoteli poza sezonem letnim. Zdrojowa Invest oferowała jednak sprzedaż apartamentów w systemie condohoteli. $\mathrm{W}$ ten sposób apartamenty były wykorzystywane całorocznie. Zdrojowa Invest stworzyła nowy rynek, wcześniej inwestorzy obawiali się, że po wybudowaniu hoteli nie będą ich w stanie utrzymać.

Umiejętność tworzenia innowacji produktowych może też być wykorzystywana do internacjonalizacji przedsiębiorstwa nawet na skalę globalną. Taka oferta wartości kierowana jest do konsumentów na różnych rynkach geograficznych i odpowiednio modyfikowana, stosowanie do ich potrzeb. Rozwiązanie takie stosowane jest przez firmę Selena, prekursora branży profesjonalnej chemii budowlanej w Polsce. 


\section{Znaczenie innowacji w modelu biznesowym}

Firmie Cyfrowy Polsat, działającej w latach 90. XX wieku na rynku płatnej telewizji cyfrowej, udało się wprowadzić innowacyjny niskokosztowy model działania. Wynikało to z konieczności dostosowania się do istniejących wówczas uwarunkowań rynkowych. Cyfrowy Polsat stworzył telewizję tanią i dostępną poza wielkimi miastami. W tradycyjnym modelu płatnej telewizji, operatorzy uzyskiwali na wyłączność prawo do transmisji szczególnie atrakcyjnych meczów piłkarskich, premier filmowych, „kupując” w ten sposób widzów. Cyfrowy Polsat z tego świadomie zrezygnował i postawił na rozrywkę, której ludziom, zwłaszcza w mniejszych miejscowościach, brakowało. Zaważyło to jednak na wizerunku, gdyż w tamtych czasach Polsat postrzegany był jako telewizja „wiejska”, grająca disco polo, a np. TVN jako telewizja ,światowa”, kosmopolityczna dla mieszkańców dużych miast. Później jednak Cyfrowy Polsat znacznie wyprzedził TVN i stał się największą firmą medialną w Polsce.

W następnych latach firma rozpoczęła budowę konglomeratu, wchodząc na rynki: telekomunikacyjny, energetyki, finansowy, ubezpieczeniowy, sprzedaży RTV i AGD, usług ochrony domu. O sukcesie takiego modelu zadecydowały m.in. efekty synergiczne, a zwłaszcza umiejętne wprowadzenie do konglomeratu zakupionego operatora telefonii komórkowej - Polkomtela.

Założono, że biznes oparty na usługach głosowych nie będzie się rozwijał, jednak łącząc potencjał usług telekomunikacyjnych, głównie transmisji danych, z posiadanymi przez firmę częstotliwościami oraz telewizją, uzyskano duży wzrost.

Działająca na rynku odzieżowym i obuwniczym firma CCC zdecydowała się na rozwijanie zakładów produkcyjnych w Europie, natomiast w tej branży większość firm stawiała na produkcję w Azji. CCC korzystała wprawdzie z możliwości rozwijania produkcji w Azji, ale głównie w odniesieniu do najtańszych wyrobów. Droższe produkowane były w Polsce. Firmie udało się połączyć stosowanie niskich cen z wielką różnorodnością oferty. Siłą firmy okazał się również eksport. W 2016 roku powierzchnia sklepów za granicą przewyższyła o $11 \%$ powierzchnię sklepów w Polsce.

Innowacyjne modele biznesowe zapewniły analizowanym przedsiębiorstwom znaczny wzrost wartości, korzystne wyniki finansowe i pozycję liderów. Innowacje produktowe są natomiast szansą, w tym dla przedsiębiorstw małych, niedysponujących odpowiednimi kompetencjami i zasobami do budowania ryzykownych, innowacyjnych modeli biznesowych. Udane innowacje produktowe mogą w krótkim czasie znacząco poprawić wyniki finansowe firmy, zwiększyć jej wartość, a nawet umożliwić internacjonalizację.

Analizowane firmy, które znacząco zwiększyły swoją wartość, osiągnęły to głównie dzięki innowacjom produktowym. Livechat wprowadził unikatowe oprogramowanie dla firm, umożliwiające prowadzenie rozmów z klientami w sieci. Uznano to za największe osiągnięcie polskich przedsiębiorców na rynku globalnych 
technologii. Globalny sukces odniosła też gra komputerowa „This War of Mine” wyprodukowana przez firmę 11 bit studios SA. Przyniosła ona $12 \mathrm{mln}$ złotych przychodu i zwiększyła pięciokrotnie wartość firmy na Giełdzie Papierów Wartościowych w Warszawie.

Biofood Ciechocin wprowadził na rynek ekologiczne soki z kwaszonych warzyw, dzięki czemu firma zwiększała swoją wartość przez trzy lata o 111\% rocznie.

Innowacje produktowe stosowane były również na dużą skalę przez firmy o ugruntowanej pozycji rynkowej i mniejszej dynamice wzrostu wartości. Wymienić tu należy firmy: Cyfrowy Polsat (wykorzystanie po raz pierwszy częstotliwości 1800 $\mathrm{MHz}$ do Internetu LTE), Polpharma (produkcja leków biopodobnych), Selena (chemia budowlana) czy Mlekovita (po raz pierwszy zastosowano na polskim rynku produkcję mleka w kartonach, stworzono też innowacyjne portfolio produktowe).

\section{Wybór sposobu ekspansji firmy}

W pracy założono, że istotnym komponentem modelu biznesowego jest charakter ekspansji. Przyjęto, że największy, trwały wzrost wartości firma może uzyskać dzięki przejęciom oraz internacjonalizacji. Z drugiej strony, sposób ekspansji oparty na takich działaniach obarczony jest najwyższym ryzykiem i wymaga od firmy unikatowych kompetencji. Z licznych badań wynika, że większość przejęć kończy się niepowodzeniem, przynosi akcjonariuszom straty lub nie daje im żadnych korzyści.

M. Porter uważa, że korporacje znacznie częściej pozbywają się przejętych firm, niż je zatrzymują. Z kolei badania KPMG wskazują na to, że ponad połowa fuzji niszczy wartość dla akcjonariuszy [Kotler, Kotler 2013, s. 156].

Z badań „Journal of Finance” wiadomo, że w ciągu pięciu lat po przeprowadzeniu transakcji firmy przejmujące odnotowują spadek wartości w wysokości $10 \%$. Stwierdzono również, że od 40 do $55 \%$ aliansów strategicznych ulega przedwczesnemu rozpadowi i przynosi straty finansowe obu partnerom [Dyer, Kale, Singh 2005, s. 102].

Istnieje jednak niewielka grupa firm, które na polu przejęć, w tym na rynkach zagranicznych, odnotowują stałe sukcesy. R.J. Aiello i M.D. Watkins uważają, że większość z nich stanowią inwestorzy funduszowi, z tego względu, że menedżerowie działający w funduszach uważają sprawy techniczne w procesie przejmowania firm za najważniejsze, tymczasem menedżerowie korporacji dokonujący przejęć strategicznych często kierują się ambicją, działają intuicyjnie, a sprawy techniczne, które są decydujące, pozostawiają prawnikom i bankowcom [Aiello, Watkins 2006, s. 30-31].

Mimo ogromnego ryzyka niepowodzeń przejęcia, w tym umożliwiające internacjonalizację, należą do najczęściej podejmowanych decyzji strategicznych, a rynek M\&A w Polsce stale rośnie.

Jak wynika z raportu Emerging Europe M\&A Report 2016/17, opracowanego przez kancelarię CMS, w 2016 roku zawarto na polskim rynku 279 fuzji i przejęć 
M\&A, których łączna wartość przekroczyła 11,2 mld euro. Najwięcej fuzji i przejęć miało miejsce w branży nieruchomości i budownictwa, w produkcji, usługach i telekomunikacji. W porównaniu z 2015 rokiem, liczba transakcji M\&A spadła, natomiast wzrósł ich wolumen [PAP 2017].

Wykorzystanie w modelach biznesowych działań z obszaru przejęć, fuzji czy konsolidacji zwiększa znacznie poziom ryzyka i niepewności.

W tej sytuacji, w warunkach wykształcania się w Polsce gospodarki rynkowej, podstawową zasadą funkcjonowania przedsiębiorstw powinno być opieranie decyzji na sprawnym systemie informacji marketingowej. Umożliwia on zmniejszanie niepewności i ryzyka w procesach decyzyjnych związanych z dokonywanymi wyborami rynkowymi oraz kształtowaniem strategii przedsiębiorstwa [Mazurek-Łopacińska (red.) 2002, s. 8].

W analizowanej grupie przedsiębiorstw o największej wartości rozwój przebiegał najczęściej według schematu: występował wzrost organiczny, pozyskiwany kapitał z giełdy umożliwiał dalszą ekspansję, następowały przejęcia na rynku krajowym i zagranicznym, rozwijany był eksport, stosowano internacjonalizację. Silną ekspansję wspomagały innowacyjne modele biznesowe, innowacje produktowe. Jedynie Cyfrowy Polsat osiągnął bardzo dużą wartość majątku bez internacjonalizacji. Było to możliwe dzięki działalności na wielu szybko rosnących rynkach krajowych (telekomunikacja, media, telefonia komórkowa, energetyka). Kluczowe dla rozwoju firmy okazały się kompetencje w zakresie przejęć, które umożliwiły w stosunkowo krótkim czasie rozwinięcie działalności na tak wielką skalę. Cyfrowy Polsat dokonał udanego przejęcia Elektrimu, Invest Banku, a przede wszystkim Polkomtela (wartość transakcji wyniosła ok. $18 \mathrm{mld}$ zł). Ta ostatnia transakcja umożliwiła firmie udane połączenie sektorów medialnego i telekomunikacyjnego.

Przejęcia okazały się również kluczową kompetencją w modelach biznesowych takich firm, jak: Getin Holding, Polpharma, Kruk, LPP, Mlekovita czy CCC. Getin Holding w latach 2002-2012 kupił lub założył 30 firm. Choć kilka z tych przedsięwzięć zakończyło się niepowodzeniem, to jednak właśnie taka strategia pozwoliła na bardzo szybki rozwój grupy [Czarnecki 2012, s. 102].

Getin Holding w modelu „funkcjonalnym” stanowi dla wszystkich podmiotów w grupie centrum kompetencji w kluczowych obszarach biznesowych. Atutem analizowanej firmy były również kompetencje związane z tworzeniem własnych firm $\mathrm{w}$ ramach holdingu. Zastanawiające jest, że menedżerowie dużych korporacji z reguły decydują się na kosztowne i ryzykowne przejęcia, a rezygnują z tworzenia własnych firm, i to mimo że mają ku temu wszelkie kompetencje i zasoby. Jednak ryzyko tworzenia nowej firmy jest tak duże, że odpowiedzialni za to menedżerowie wolą go nie podejmować.

W analizowanym przedsiębiorstwie Getin Holding tworzenie nowych firm wykorzystano jako czynnik motywacyjny dla kadry menedżerskiej. Chęć prowadzenia samodzielnego projektu i możliwość rozwoju biznesowej kariery okazała się bardzo silnym czynnikiem motywacyjnym [Czarnecki 2012, s. 330-331]. 


\section{Podsumowanie}

Propozycja wartości dla klienta (CVP), czyli pomoc dla klientów w wykonaniu pewnego zadania, rozwiązaniu fundamentalnego problemu jest najważniejszym komponentem modelu biznesowego. Badane przedsiębiorstwa osiągnęły dużą wartość majątku i wysoką dynamikę jego wzrostu głównie dzięki unikatowej propozycji wartości. Większość uzyskanych efektów w zakresie oferowanej odbiorcy wartości wiązała się ze stosowaniem innowacji: produktu, procesu, marketingu czy modelu biznesowego.

Analizowano dwie grupy przedsiębiorstw: o największej wartości spośród polskich firm prywatnych oraz o najwyższej dynamice wzrostu wartości. W grupie największych polskich firm prywatnych w stosowanych modelach biznesowych dominujące znaczenie miały:

- wzrost organiczny na rodzimym rynku, osiągnięty dzięki umiejętnemu pozyskiwaniu kapitału, w tym zwłaszcza z Giełdy Papierów Wartościowych,

- wysokie kompetencje w dziedzinie przejęć innych firm (również na rynkach zagranicznych) i w tworzeniu własnych firm,

- szybka internacjonalizacja działalności.

Działania w zakresie przejęć, tworzenia własnych firm oraz internacjonalizacji na wielką skalę wiązały się z wysokim poziomem ryzyka, ale umożliwiały szybki wzrost wartości, osiągnięcie dominującej pozycji rynkowej.

W modelach biznesowych firm o wysokiej dynamice wzrostu wartości największe znaczenie miały: umiejętność pozyskiwania finansowania, $w$ tym z rynku kapitałowego, umiejętność wykorzystywania trendów społecznych, innowacje produktowe, unikatowe kompetencje umożliwiające szybkie wchodzenie na rynki zagraniczne (tzw. urodzeni globaliści).

Prezentowane wyniki badań mogą być wykorzystywane przy tworzeniu modeli biznesowych, zwłaszcza w przedsiębiorstwach zakładających w planach strategicznych długotrwały i dynamiczny wzrost wartości majątku.

\section{Literatura}

Aiello R.J., Watkins M.D., 2006, Od informacji do transakcji - pięć etapów udanego przejęcia, [w:] Fuzje i przejęcia, Harvard Business Review, Wydawnictwo Helion, Gliwice.

Chan Kim W., Mauborgne R., 2003, Tworzenie nowych przestrzeni rynkowych, [w:] Zarzadzanie innowacja, Harvard Business Review, Wydawnictwo Helion, Gliwice.

Czarnecki L., 2012, Biznes po prostu. Nastepny krok, Muza SA, Warszawa.

Dyer J.H., Kale P., Singh H., 2005, Jak wybrać między przejęciem a aliansem strategicznym, [w:] Zarządzanie wzrostem przychodów, Harvard Business Review, Wydawnictwo Helion, Gliwice.

Golik-Górecka G., 2008, Interfejs marketingowo-finansowy $w$ analizach portfelowych wspomagajacych strategie marketingowe, [w:] Mazurek-Łopacińska K. (red.), Marketing. Problemy teorii i praktyki marketingu, Wydawnictwo Uniwersytetu Ekonomicznego we Wrocławiu, Wrocław. 
Johnson M.W., Christensen C.M., Kagermann H., 2012, Jak fundamentalnie zmienić model biznesowy firmy, [w:] O strategii, Harvard Business Review, Wydawnictwo Ican Institute, Warszawa.

Kalinowski T.B., 2010, Innowacyjność przedsiębiorstw a systemy zarzązania jakościa, Wolters Kluwer, Warszawa.

Kotler P., Kotler M., 2013, Przez marketing do wzrostu. 8 zwycięskich strategii, Dom Wydawniczy Rebis, Poznań.

Mazurek-Łopacińska K. (red.), 2002, Badania marketingowe. Podstawowe metody i obszary zastosowań, Wydawnictwo Akademii Ekonomicznej we Wrocławiu, Wrocław.

Moore G.A., 2005, Innowacja w rozwiniętych firmach, [w:] Zarządzanie wzrostem przychodów, Harvard Business Review, Wydawnictwo Helion, Gliwice.

Prahalad C.K., Krishnan M.S., 2010, Nowa era innowacji, Wydawnictwa Profesjonalne PWN, Warszawa.

Szymura-Tyc M., 2012, Wspótczesne procesy innowacyjne w ksztattowaniu produktów systemowych, [w:] Żabiński L. (red.), Marketing produktów systemowych, Polskie Wydawnictwo Ekonomiczne, Warszawa.

Trias de Bes F., Kotler P., 2013, Innowacyjność przepis na sukces. Model od A do F, Dom Wydawniczy Rebis, Poznań.

\section{Raporty, źródla internetowe}

Lista 100. Największe polskie firmy prywatne, 2016, Miesięcznik Forbes, listopad.

PAP, 2017, Rekord fuzji i przejęć w Polsce. Łączna wartość przekroczyła 11,2 mld euro, http://businessinsider.com.pl/finanse/firmy/fuzje-i-przejecia-w-polsce-w-2016-roku/x74wrsr (21.04.2018).

Raport Diamenty miesięcznika Forbes, 2017, Miesięcznik Forbes, grudzień. 